\title{
A Study on the Relationship between the Typology of Knowledge-Intensive Businesses (KIBs) and Performance Measurement Systems (PMS): Evidence from Taiwan
}

\author{
Cheng-Tsung $\mathrm{Lu}^{1} \&$ Yeun-Wen Chang ${ }^{2}$ \\ ${ }^{1}$ Department of Accounting Information, National Taichung University of Science and Technology, Taichung, \\ Taiwan (ROC) \\ ${ }^{2}$ Department of Public Finance and Taxation, National Taichung University of Science and Technology, Taichung, \\ Taiwan (ROC) \\ Correspondence: Cheng-Tsung Lu, Department of Accounting Information, National Taichung University of Science \\ and Technology, Taiwan (ROC)
}

Received: June 2, 2016

Accepted: August 7, 2016

Online Published: October 14, 2016

doi:10.5430/afr.v5n4p89

URL: http://dx.doi.org/10.5430/afr.v5n4p89

\begin{abstract}
This study utilizes the source of knowledge (internal or external) to derive four types of knowledge-intensive businesses (KIBs): non-KIB, knowledge creator, knowledge introducer, and knowledge integrator. Moreover, this study investigates the differences among the four types of KIB in their organizational characteristics and performance measurement system (PMS). The proposed model is empirically evaluated using survey data collected from top or middle managers of 127 Taiwan companies in which 109 companies are classified as KIBs. Based on the analysis of multiple regressions and MANOVA, the empirical results reveal that there are significant differences in the organizational characteristics and PMS among the four types of KIBs. There are three main contributions in this research: (1) we categorize the KIBs into four types by using the main source of internal or external knowledge in the companies. This typology of KIBs would contribute to our understanding of knowledge management. (2) This study uses environmental uncertainty, innovation strategy, size and absorptive capacity to construct the organizational configuration of different KIBs. (3) We find that there are significant differences among the four types of KIB in the financial or non-financial PMS.
\end{abstract}

Keywords: Knowledge-intensive businesses (KIBs), Knowledge management, Performance measurement system (PMS)

\section{Introduction}

Managers usually use performance measurement system (PMS) to evaluate various operational activities in order to collect the information regarding the efficiency of resources allocation (Robinson and McDougall, 1998; Artz, Homburg, and Rajab, 2012; Arnold and Artz, 2015). The results of measurement would be the references for future decision-making and resource reallocation (Bai, Coronado, and Krishnan, 2010; Abernethy, Bouwens, and Lent, 2013). Therefore, the designing of effective PMS would facilitate the management control and resource allocation activities for managers and become a critical factor for the business operation (O'Connor, Deng and Luo, 2005). However, according to the investigations of Marginsona, McAulayb, Roushc, and Zijl (2014), only 15 percent of the respondents' PMS supports top management's business objectives well. Ittner and Larcker (2001) propose the framework of value-based management accounting, and they suggest the firms should identify the specific performance variables, or "value drivers", that actually create value in the business given the organization's strategies and organizational design. Therefore, a considerable number of recent studies have been suggested that the firms should develop the PMS to meet the organizational culture (Henri, 2006; Artz et al., 2012), organization design (Arnold and Artz, 2015; Demeré, Krishnan, Sedatole, and Woods, 2016), and strategic goals of companies (Ittner and Larcker, 2003; Marginsona et al., 2014). In other words, the design of PMS is an important research issue in management accounting (Abernethy et al., 2013; Ho, Wu, and Wu, 2014; Sari and Basri, 2015; Demeré et al., 2016).

In recent years, the enterprises place important on the managerial and operational knowledge that would be the crucial factors to sustain the profitable businesses and consolidate the leading position in the era of knowledge economy (Gopalakrishnan, Libby, Samuels, and Swenson, 2015). We have seen the emergence of the 
knowledge-intensive businesses (KIBs), on the basis of which, knowledge and the capability to create and utilize such knowledge are the most important sources of competitive advantage (Bettencourt, Ostrom, Brown, and Roundtree, 2002; Ditillo, 2004; Murray, Kotabe, and Westjohn, 2009; Najafi-Tavani, Zaefarian, Henneberg, Naude, Giroud, and Andersson, 2015). KIBs provide not only tangible goods but also intangible knowledge service in this competitive era, typical examples of these companies are law and accounting firms, software companies, department stores etc. (Murray et al., 2009; Najafi-Tavani et al., 2015). Hence, the PMS of KIBs could not just focus on the traditional financial indicators. According to the suggestions of Ittner and Larcker (1998), the PMS should include the non-financial perspectives to measure the performance and there should be difference between the financial and non-financial perspectives in different KIBs. Ditillo (2004) examines how knowledge complexity affects coordination and knowledge integration, and in turn management control systems. A field research conducted in three project teams of a software firms supports the contingent relationships are analyzed in the realm of KIBs' teams, where the problems of consistency between coordinating individuals and integrating knowledge mostly occur. However, the measures of PMS for KIBs still lack consistent opinions, and thus the issue would be deserved to be examined.

Leonard-Barton (1995) and Jordan and Jones (1997) indicate that the sources of knowledge could be from internal and external to the company. Therefore, this study based on the concepts of Leonard-Barton (1995) and Jordan and Jones (1997) to categorize the KIBs into four types, including "knowledge creator", knowledge introducer, knowledge integrator and non-knowledge intensive business". This study proposes the classification of KIBs would be the main contribution to accumulate the research findings of knowledge management. Besides, the literature of performance measurement also emphasizes the importance of integrating multiple dimensions for PMS (Abernethy et al., 2013; Ho et al., 2014; Arnold and Artz, 2015; Sari and Basri, 2015). Thus, this study adopts the concept of balanced scorecard (BSC) to modify the dimensions of PMS (Kaplan and Norton, 1996), including the financial, customer, internal business process, and human capital perspectives. Then, we extend the study of Bettencourt et al. (2002) and investigate whether there are any differences among the four types of KIBs in the dimensions of PMS. This would be another contribution of our study to integrate the performance measurement into the research issue of knowledge management. Based on a sample of KIBs that are listed on the publications of China Credit Information Service Company in Taiwan, we find that (1) KIBs could be categorized into four types by using the main source of internal or external knowledge in the companies. (2) The organizational characteristics of different KIBs would influence the design of PMS and the choice between internal or external knowledge. (3) We find that there are significant differences among the four types of KIB in the multiple dimensions of PMS.

In sum, there are three research questions in this study: (1) Is there any relationship between the organizational characteristics and the sources of knowledge? In this research, we categorize the KIB into four types by examining the internal and external knowledge. We also explore the relationship between the organizational characteristics (environment, size, innovation strategy and absorptive capacity) and the sources of knowledge to capture the configuration of different KIBs. (2) Is there any relationship between the organizational characteristics and PMS? (3) Is there any relationship between the source of knowledge and PMS? And what are the differences in the PMS of these four KIBs? This study hopes to investigate the PMS among different KIBs.

The remainder of the paper is organized as follows. Section 2 discusses prior literature and develops the hypotheses. Section 3 discusses the research design and Section 4 presents the results of the empirical tests. Section 5 concludes the paper.

\section{Literature Review and Hypotheses Development}

\subsection{The Sources of Knowledge in the KIBs}

Knowledge management is one of the most important tasks of organizational managers. Identifying the sources of internal and external knowledge can help organizational managers to control their organizations more effectively and to avoid conflicts that can arise in these high-pressure environments (Riasi and Asadzadeh, 2016). Many scholars indicate that the sources of organizational knowledge could be from internally and externally oriented activities of this organization (Leonard-Barton, 1995; Jordan and Jones, 1997). The sources of internal knowledge include the cooperation of R \& D activities, the database of MIS and documents. The external knowledge could be from the new ideas of development trend and the alliance or cooperation of different organizations (Jordan and Jones, 1997). Zack (1999) also states that the sources of knowledge may lie within or outside the firm. Internal knowledge may be resident within people's head, embedded in behaviors, procedures, software and equipment, recorded in various documents or stored in databases and online repositories. In the contrast, the sources of external knowledge include inter-organizational alliances, publications, professional associations, consultant vendors, universities, government 
agencies, knowledge brokers, and personal relations (Zack, 1999). Therefore, the internal and external knowledge are the sources of core competency for KIBs to attain the sustainable competitive advantage (Bettencourt et al., 2002). The sources of knowledge in this study can be divided into internal and external knowledge. The definitions are listed as follows:

(1) External knowledge can be defined as the knowledge that acquired or absorbed outside the organization, such as transfer information or know-how from parent company or inter-organizational alliances. The organization will apply this knowledge to achieve the purpose of strategy (Leonard-Barton, 1995; Jordan and Jones, 1997; Zack, 1999).

(2) Internal knowledge can be defined as the knowledge that created or developed by the organization members themselves. The organization will apply this knowledge to generate more innovation in products or service (Leonard-Barton, 1995; Jordan and Jones, 1997; Zack, 1999).

\subsection{The Types of KIBs}

Based on the internal or external source of knowledge, this study categorizes the KIBs into four types: knowledge creator, knowledge introducer, knowledge integrator, and non-KIB (displayed in Figure 1). Companies of the non-KIB show little interest or effort in knowledge management, and these companies often use traditional ways to manage and operate the company without accumulating useful internal or external knowledge. Non-KIB would be out of the market quickly in the turbulent and knowledge-intensive business environment. Companies of knowledge creator put more emphasis on the innovation and development of knowledge from internal organization to generate the core competitive advantage. They often use innovation and marketing differentiation strategies to build the leader and unique image in the related industries (e.g. IBM, Intel, Sony, and Honda, etc) (Biege, Lay, Zanker, and Schmall, 2013). The famous bicycle manufacturer of Giant and handheld devices ODMs (original design manufacturers) of High Tech Computer are all good examples of knowledge creator companies in Taiwan. These famous companies all emphasize on the value of human resources and use them for continuous innovation activities to sustain the leader position in related industries. The managerial and operational knowledge of these companies are mainly from the internal organizations by using R \& D and documenting tacit knowledge stored in human resources (Miozzo, Desyllas, Lee, and Miles, 2016). Therefore, we define these companies as the knowledge creator.

There are only few companies that can develop the core competence solely by themselves and most companies often need external knowledge to sustain their managerial and operational activities. These companies often introduce knowledge by using strategic alliances or technologies transformations to obtain the core competence in the related industries (Jordan and Jones, 1997; Zack, 1999). They can reduce the learning and fumbling time of entering new businesses or manufacturing new products, which they had no related experience before. They take this strategy of introducing knowledge outside the company in order to increase the market share quickly and save the time or cost of developing related knowledge. Many department stores, hospitals or distribution industries all use this strategy to become the leaders in the related industries. Therefore, we regard these companies as the knowledge introducer in our study. With regard to the companies of knowledge integrator, they emphasize both internally and externally oriented knowledge, and thus, they are more integrative and aggressive (Ditillo, 2004). The management consulting companies (e.g. KPMG or Deloitte \& Touche) have to introduce and assimilate new knowledge continuously from different perspectives, and apply it with the tacit knowledge to solve the customized problems. $3 \mathrm{M}$ is another example of knowledge integrator. 3M applies the core competence of stick technologies to different products (e.g. stationery, medical, and traffic, etc). This company has to absorb the new development of knowledge and explore the demands of different customers continuously, and apply the ability of innovation and integration to solve the customized problems (Marjanovic and Freeze, 2012). Therefore, knowledge integrator provides the customized products or services. Based on the above arguments, we regard these companies as the knowledge integrator in our study. 


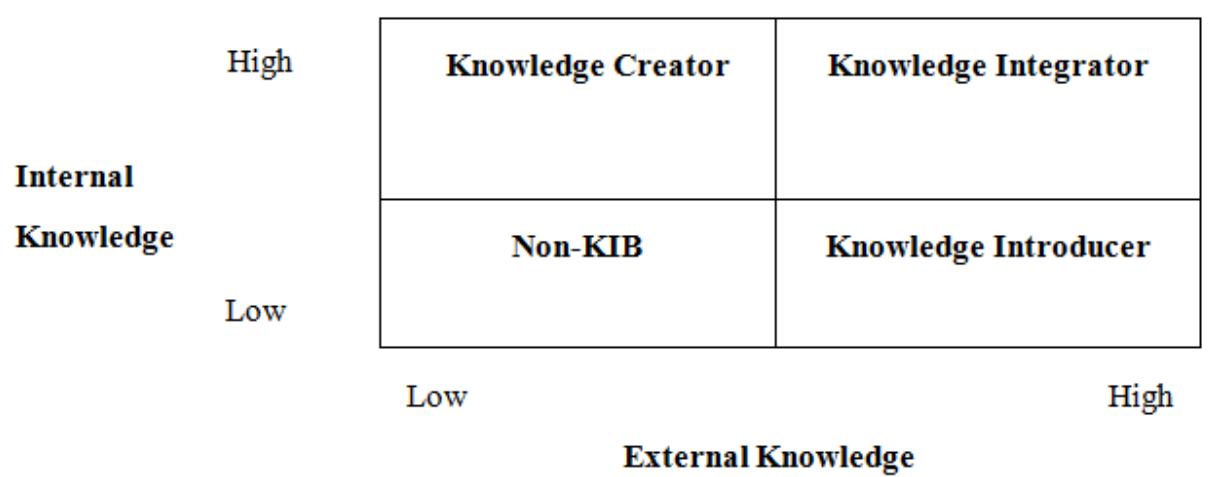

Figure 1. Four types of KIBs

\subsection{The Characteristics of Knowledge-Intensive Business (KIBs)}

The main profit and competitive advantage of KIBs are from the results of knowledge commercialization, which is created by human resources in the KIBs (Najafi-Tavani et al., 2015). Bettencourt et al. (2002) also argue that the primary value-added activities of KIBs are consisting of the accumulation, creation or dissemination of knowledge for the purpose to develop a customization service or product solution to satisfy the customers' demand. Hence, the activities of KIBs are complex, unstructured, and highly customized. Santos and Spring (2015) also indicate that the characteristics of KIBs include: (1) people possess the know-how and network relationship in the KIBs. If people leave the firm, intellectual capital will go with them; (2) Knowledge workers need information about the strategy of the firm in order to make decisions effectively; (3) In order to react more quickly to dynamic environmental changes, the KIBs need to have excellent learning capabilities; and (4) Tight focus on achieving goals might hamper innovation in the KIBs. Therefore, based on the above literature review, we adopt four characteristics to formulate the configuration of KIBs, including environment, innovation strategy, size and absorptive capacity.

\subsubsection{Environment}

Organizations that have higher levels of competition are likely to depend more on the knowledge and experience and thus face higher knowledge transfer costs. The delegation of decision authority to divisional managers enables them to effectively use their information advantage to quickly respond to the environment (O'Connor et al., 2005). External environment of KIBs is often dynamic and unpredictable (Biege et al., 2013), so the external environment of KIBs is highly uncertain. This study adopts the measurement items developed by Duncan (1972), and Gordon and Narayanan (1984) to measure the environmental uncertainty. The external environment for businesses has become a hyper-competition and firms can not maintain the sustainable competitive advantage through single traditional operational advantage. Companies have to adopt multi-skills and continuous improvement to catch up the change of competition environment (Marjanovic and Freeze, 2012). Based on the above discussion, we use environmental uncertainty to measure the external environment of KIBs. Chenhall and Morris (1986) states that when environment becpmes more complex, the decision makers would face more diversified information. Taking account of the R\&D cost and entering the market immediately, the organization would put emphasis on the external knowledge (Zack, 1999). This study formulates the hypothesis as follows:

H1a: Environment uncertainty is positively related to the external knowledge.

\subsubsection{Innovation Strategy}

KIBs' operating activities are complex, unstructured and customized, the employees have to acquire the knowledge for developing new products, technologies and processes (Bettencourt et al., 2002). KIBs have been characterized as those that deploy their "assets in a distinctive way, for they sell a capacity to produce, rather than a product" and finally those that process what they know into unique knowledge products and services for their customers, or possibly goods in combination with services (Miozzo et al., 2016). Hence, KIBs must put emphasis on innovation strategy. This study adopts the concept proposed by Veugelers and Cassiman (1999) who argue that the innovation strategy includes: (1) The in-house R\&D knowledge called MAKE decision; (2) The knowledge acquired outside the firm called BUY decision. Many scholars suggest that MAKE decision includes the R\&D knowledge within the company or the group (Conant, Mokwa, and Varadarajan, 1990; Padmore, Schuetze, and Gibson, 1998). On the contrary, BUY decision includes the knowledge outside the firms (suppliers, customers, licensing, colleges etc.). 
Hence, this study proposes that different levels of innovation will influence the choice between internal and external knowledge. The hypothesis is as follows:

$\mathrm{H} 1 \mathrm{~b}$ : The level of innovation is positively related to the internal knowledge.

\subsubsection{Size}

The difference among the organizational activities, the limited items of technology and size is diversity (Child, 1972). In other words, the organizational size has relations with the characteristics of related organizational activities. Child (1972) argues that the importance of the fitness between the organizational size and operational activities, and he suggests that different kinds of size structure should fit with core technology. To advance the core technology, the organization must shape into functional divisions and complex roles (Abernethy et al., 2013). Veugelers and Cassiman (1999) identify that the large-sized enterprises have copiously finance and human capital, so they acquire core technology in-house. On the contrary, small and middle enterprises take cost into account when they are engaged in R\&D. So they acquire core technology by building and linking the relationship outside the enterprises. This study uses the number of employees (Veugelers and Cassiman, 1999) to measure the organizational size. So the hypothesis is established as follows:

H1c : The organization size is positively related to the internal knowledge.

\subsubsection{Absorptive Capacity}

For the sake of accumulating competitive advantage, the KIBs have to learn about the newly developed knowledge from internal and external organization. Hurley and Hult (1998) also state that organizational learning is a key antecedent of innovation. Therefore, organizations are seen to manage knowledge which implies that any individual learning requires some substantiation of the essence of learning that leads to the accumulation of knowledge (Giotopoulos, 2014). The most relevant construct with regards to KIBs is absorptive capacity. Absorptive capacity can be defined as a firm's ability to recognize the value of new external information, assimilate it, and apply it commercially (Cohen and Levinthal, 1990). It has two dimensions: knowledge assimilation and knowledge integration. This study also adopts these two dimensions to measure the absorptive capacity of KIBs. With regard to the knowledge assimilation, Cohen and Levinthal (1990) indicate that the firms should collect many sources of knowledge for the employee as the bases of innovation. Moreover, Cohen and Levinthal (1990) state that knowledge integration cares about the application and integration of different sources of knowledge to managerial and operational activities (e.g. $\mathrm{R} \& \mathrm{D}$, manufacturing, marketing, etc.). When the absorptive capacity is high, the organization will create knowledge in-house. Otherwise, the organization will acquire knowledge from strategic licensing (Giotopoulos, 2014). This study formulates the hypothesis as follows:

H1d: Absorptive capacity is positively related to the internal knowledge.

From what has been discussed and inferred above, we formulate the hypothesis 1.

H1: Different organizational characteristics will influence the choice between internal and external knowledge.

\subsection{The Relationship among Organization Characteristics, PMS, and the Source of Knowledge}

\subsubsection{Performance Measurement System (PMS)}

KIBs provide not only tangible goods but also intangible knowledge service in this competitive era (Miozzo et al., 2016). Hence, the PMS of KIBs could not just focus on the traditional financial dimension but also nonfinancial dimension. Ittner, Larcker and Rajan (1997) examine the choice of performance measures of CEO's annual bonus contracts from 317 firms, and they find that the relative weight placed on non-financial measures. The use of financial and non-financial measures simultaneously will ensure that the management incentives and organizational strategy are aligned. According to the concept of BSC, multiple dimensions of PMS should integrate financial, customer, internal business process, learning and growth perspectives (Kaplan and Norton, 1996). Moore, Rowe, and Widener (2001) indicate that human capital performance is more important than learning and growth perspectives of PMS. Besides, Sari and Basri (2015) state that effective PMS should incorporate multiple financial and non-financial measures. But Demeré et al. (2016) also suggest that mutual consistency among multiple performance dimensions may be problematic when these multiple measures are disaggregated into partial sets of measures in functional subunits. Besides, "control value firms" may emphasize mainly financial measures, but "flexibility value firms" may use various non-financial measures as complement to financial measures in order to focus organizational attention and foster internal communication (Henri, 2006). Different kinds of KIBs have their own organizational value, and that also have influence on the design of PMS. Hence, these measures and dimensions of PMS emphasize many attributes including causal connections with strategy, integrating actions across functional boundaries, and supporting 
with effective target setting and reward systems (Ho et al., 2014). However, the measures of PMS for KIBs still lack consistent opinions, and we summarize the performance measurement indicators of four perspectives in this study.

\subsubsection{Environment Uncertainty and PMS}

Environmental complex is related to the heterogeneity of organizational activities and the range of environment (Chenhall and Morris, 1986). When the organization faces the environmental uncertainty, the decision makers also lack accurate information about the result of decision. Organizations have higher levels of competition are likely to depend more on the knowledge and thus face higher knowledge transfer costs (Thomas, 1998). Because there is pressure on management to make accurate judgments about manager performance with respect to quality, delivery and budget targets, which in turn increases the need for more extensive controls such as multiple dimensions of PMS (Kruis and Widener, 2014). This study proposes that the more complex and uncertain environment is, the more the organization needs multiple dimensions for PMS. Thus, the hypothesis is established as follows.

H2a: Environmental uncertainty will affect the four perspectives of PMS.

\subsubsection{Innovation Strategy and PMS}

Enterprises give weight to innovation strategy must acquire, renew technological knowledge from MAKE decision or BUY decision to satisfy the customers' particular need (Veugelers and Cassiman, 1999). Hence, the design of PMS not only takes account of financial measures, but also the measurements of $R \& D$, learning capability, and other value chain activities. Non-financial measures can foster curiosity and stimulate organizational reform, favoring the emergence of new strategies and learning (Bai et al., 2010). Arnold and Artz (2015) also find that the relative weight placed on non-financial measures is greater in firms following an innovation strategy. On the other hand, KIBs create synergy to increase the integrated application of specialized knowledge, so that the performance of the whole is greater that the sum of its parts (Ditillo, 2004). In fact, complex tasks require the search for and evaluation of various perspectives and a complete PMS will help KIBs to understand the outcome and variance of the strategy implementing. Thus, this study formulates the hypothesis as follows:

H2b: The innovation strategy will affect the four perspectives of PMS.

\subsubsection{Size and PMS}

Marginsona (2014) identifies that different strategic attribution can't use the same PMS. It means that different kinds of departments or SBUs should build the multiple dimensions of PMS that fits the departmental objectives. The bureaucracy would enlarge with the organizational members (Child, 1972), so the design of PMS in KIBs should include various financial and non-financial measures. This study formulates the hypothesis as follow:

H2c: The organization size will affect the four perspectives of PMS.

\subsubsection{Absorptive Capacity and PMS}

The organization training can foster the employee's learning and innovation capability (Cheng and Humphreys, 2012). The educational training is one of the main sources of absorptive capacity (Cohen and Levinthal, 1990). From the perspective of internal process, knowledge integration focuses on the application and integration of different sources of knowledge to managerial and operational activities (e.g. R \& D, manufacturing, marketing, etc.) (Kaplan and Norton, 1996). In other words, learning at the organization level is seen to increase the knowledge intensity of the organization which is a prerequisite for developing strategic responses, and integrative PMS are potentially a primary tool for mapping, evaluating and learning about strategic direction. In sum, the absorptive capacity of a firm must be related to its PMS. PMS will help the firm to understand KIBs' learning and innovation capability. Thus, this study formulates the hypothesis as follow:

H2d: The absorptive capacity will affect the four perspectives of PMS.

In sum, we integrate the hypothesis $\mathrm{H} 2 \mathrm{a} \sim \mathrm{H} 2 \mathrm{~d}$ as follows:

H2: Different organizational characteristics will affect the design of PMS.

\subsection{The Source of Knowledge and PMS}

Çiçek, Köksal and Özdemirel (2005) state that structure will influence the organizational performance. Structure refers to characteristics of organization related to its maturity and capability, such as knowledge, and skill for quality. The internal and external knowledge are also the sources of core competency for KIBs to attain the sustainable competitive advantage. Internal knowledge is the knowledge that is created or developed by the organizational members themselves, and the organization will apply this knowledge to generate more innovation in products or service (Zack, 1999). From the premise of offering customized products/services, the R\&D department would be the 
pioneer. In other words, the organization putting emphasis on internal knowledge activity must also enhance the employees' learning capability, and customers' value proposition. Hence, the PMS also should be designed to fit the knowledge types. On the other hand, external knowledge is the knowledge that is acquired or absorbed outside the organization, such as transfer information or know-how from parent company or inter-organizational alliances, and then the organization will apply this knowledge to achieve the purpose of strategy (Leonard-Barton, 1995; Jordan and Jones, 1997). Based on the reasons of cost and time saving, the organizations can enter the market rapidly and avoid the failure of R\&D. So this type of organization must put emphasis on absorbing the external knowledge. The PMS is taken account of financial measures. This study formulates the hypothesis as follow:

H3: Different sources of knowledge will affect the design of PMS.

\subsection{The Type of KIBs and PMS}

The design of PMS should emphasize on the fitness between the measurement indicators and the organizational contextual factors in order to enhance the final performance (Cheng and Humphreys, 2012). This study categorizes KIBs into four types: knowledge creator, knowledge introducer, knowledge integrator, and non-KIB. Because these KIBs have different strategic objectives, the performance measures of PMS should be different in order to reflect the performance exactly. Therefore, we formulate the hypotheses as follows:

H4: Different types of KIBs have significant differences in PMS.

\section{Methodology}

\subsection{Research Model and Methodology}

Based on the hypotheses discussed above, this study formulates the research model in Figure 2. The measurement items used in this study are all based on the related studies and the items are measured on a seven-point Likert scale ranging from "given the least agreement or emphasis" to "given the most agreement or emphasis". Appendix shows the items of questionnaires. According to the research model in Figure 2, we use multiple regressions to test H1 which investigates the relationship between the organizational characteristics and the sources of knowledge. Then we also use multiple regressions to test $\mathrm{H} 2$ and $\mathrm{H} 3$ that investigate the relationship among the organizational characteristics, the sources of knowledge, and PMS. Finally, based on the analysis of multivariate analysis of variance (MANOVA), we test $\mathrm{H} 4$ to investigate the differences between the four types of KIBs and PMS.

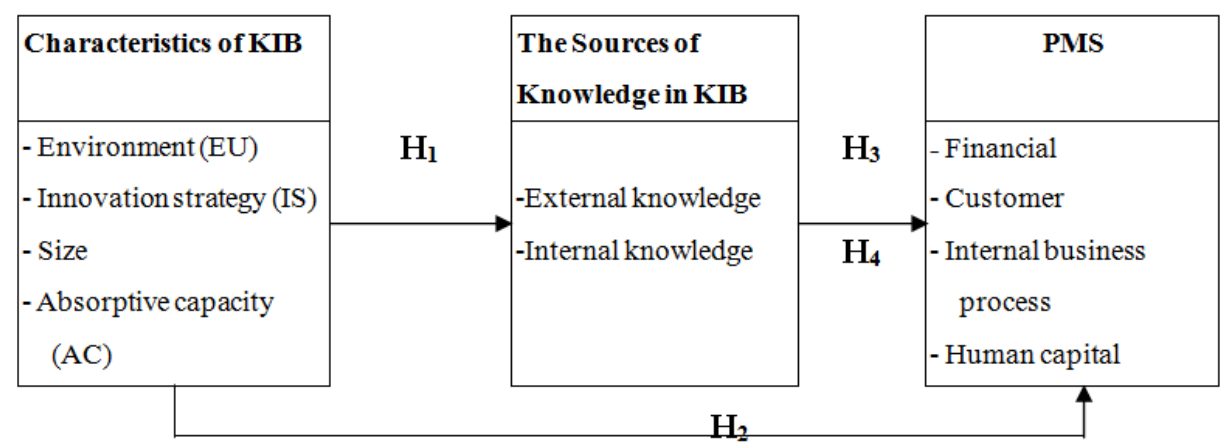

Figure 2. Research Model

\subsection{Data Collection and Sampling Procedure}

A pilot-test is performed using ten EMBA students in Taiwan. Pilot-test results indicate that the instrument contains no ambiguities and its length was reasonable. A thousand of survey questionnaires are randomly mailed to the top managers (e.g. general manager, vice general manager, and associate general manager, etc) from companies listed on the publications of China Credit Information Service Company in Taiwan. The managers are asked to answer the questions regarding the sources of knowledge, the characteristics of their company, and rate the importance of each dimension of PMS that is actually placed by their company. In order to increase the response rate, the follow-up calls are made via phone and e-mail 3 weeks after mailed. As a result, 139 questionnaires returned from top and middle managers with 12 invalid samples, achieving a response rate of $12.7 \%$.

\subsection{Types of KIBs}

This study adopts the K-means cluster analysis to derive the four types of KIBs. Table 1 shows the result of cluster analysis by using K-means technique. Because their means are significantly different at the level of 0.01 confidence 
level, it is reasonable to categorize the KIBs into four types. As a result of the clustering analysis, 46 firms are categorized into cluster 1, 38 firms into cluster 2, 25 firms into cluster 3 and 18 firms into cluster 4 . The firms in cluster 1 have high degree in two sources of knowledge, and we define the cluster 1 as the knowledge integrator in this study. The firms in cluster 2 have low degree of internal knowledge and high degree of external knowledge, which can be defined as knowledge introducer. Cluster 3 has high degree of internal knowledge and low degree of external knowledge, which can be defined as knowledge Creator. The cluster 4 has low degree in both two sources of knowledge, so it can be called as non-KIB firm. In which 109 companies are classified as KIBs. Table 2 shows the demographic profile of 109 companies of KIBs.

Table 1. K-means cluster analysis for the types of KIB

\begin{tabular}{|c|c|c|c|c|c|c|}
\hline & \multicolumn{4}{|c|}{ Clusters } & \multirow[t]{2}{*}{ F-value } & \multirow[t]{2}{*}{ P-value } \\
\hline & $\begin{array}{c}1 . \\
\text { Integrator } \\
(\mathrm{n}=46)\end{array}$ & $\begin{array}{c}2 . \\
\text { Introducer } \\
\quad(n=38) \\
\end{array}$ & $\begin{array}{c}3 . \\
\text { Creator } \\
(\mathrm{n}=25)\end{array}$ & $\begin{array}{c}4 . \\
\text { Non-KIB } \\
(\mathrm{n}=18)\end{array}$ & & \\
\hline Percentage & $36.22 \%$ & $29.92 \%$ & $19.69 \%$ & $14.17 \%$ & & \\
\hline $\begin{array}{l}\text { Internal } \\
\text { knowledge }\end{array}$ & $\begin{array}{c}6.57 \\
\text { (High) }\end{array}$ & $\begin{array}{c}5.47 \\
\text { (Low) }\end{array}$ & $\begin{array}{c}6.38 \\
\text { (High) }\end{array}$ & $\begin{array}{c}4.75 \\
\text { (Low) }\end{array}$ & 200.937 & 0.000 \\
\hline $\begin{array}{l}\text { External } \\
\text { knowledge }\end{array}$ & $\begin{array}{c}5.90 \\
\text { (High) }\end{array}$ & $\begin{array}{c}5.21 \\
\text { (High) }\end{array}$ & $\begin{array}{c}4.44 \\
\text { (Low) }\end{array}$ & $\begin{array}{c}4.26 \\
\text { (Low) }\end{array}$ & 298.735 & 0.000 \\
\hline
\end{tabular}

Table 2. Demographic Profile of KIBs ( $\mathrm{n}=109)$

\begin{tabular}{|c|c|c|c|}
\hline \multirow[b]{2}{*}{ Attributes } & \multicolumn{3}{|c|}{ Departmental managers } \\
\hline & Items & Frequency & Percent \\
\hline \multirow[t]{7}{*}{ Industry } & Pharmaceutics (biotechnology) & 17 & $15.60 \%$ \\
\hline & High-tech ( software, electronics et al. ) & 54 & $49.54 \%$ \\
\hline & Management consulting & 9 & $8.26 \%$ \\
\hline & Banking & 15 & $13.76 \%$ \\
\hline & Manfacturing & 6 & $5.50 \%$ \\
\hline & Construction & 4 & $3.67 \%$ \\
\hline & Selling (department store, ) & 4 & $3.67 \%$ \\
\hline \multirow{6}{*}{$\begin{array}{l}\text { Number of the } \\
\text { employees }\end{array}$} & Below 100 & 1 & $1.11 \%$ \\
\hline & $101 \sim 200$ & 20 & $18.35 \%$ \\
\hline & $201 \sim 500$ & 18 & $16.51 \%$ \\
\hline & $501 \sim 1000$ & 36 & $33.03 \%$ \\
\hline & $1001 \sim 2000$ & 18 & $16.51 \%$ \\
\hline & Above 2000 & 16 & $14.49 \%$ \\
\hline \multicolumn{2}{|c|}{ Average of sales in Under $\$ 50$ million } & 3 & $2.36 \%$ \\
\hline \multirow[t]{6}{*}{ three years } & $\$ 50$ million $\sim \$ 100$ million & 6 & $4.72 \%$ \\
\hline & $\$ 500$ million $\sim \$ 1$ billion & 2 & $1.57 \%$ \\
\hline & $\$ 1$ billion $\sim 5$ billion & 14 & $11.02 \%$ \\
\hline & $\$ 10$ billion $\$ 20$ billion & 55 & $43.31 \%$ \\
\hline & $\$ 10$ billion $\sim 20$ billion & 27 & $21.26 \%$ \\
\hline & Above $\$ 20$ billion & 20 & $15.76 \%$ \\
\hline
\end{tabular}

\section{Data Analysis}

\subsection{General Findings}

The Cronbach's aof reliability coefficients for the scales are above the commonly applied standard of 0.6 , and it shows the reasonable item convergence in this study (Cuieford, 1965). We also use factor analysis to test the 
construct validity. The correlation of item with total score-item (the item-to-total correlation), between each item and the sum of the remaining items, is used for convergent validity (Kerlinger, 1986) and the item-to-total correlation score that is lower than 0.4 should be eliminated. We also use factor analysis to check discriminate validity. The factor analysis with varimax is employed to check uni-dimensionality among the items, and those with factor loading values lower than 0.5 should be eliminated (Kerlinger, 1986). The convergent validity and discriminate validity of this study should be reasonable. Table 3 presents means, standard deviations, and response ranges for the variables.

Table 3. Descriptive statistics

\begin{tabular}{|c|c|c|c|c|}
\hline Variables & Mean & Standard deviation & Theoretical range & Actual range \\
\hline Internal knowledge & 6.1422 & 0.5857 & $1-7$ & $5.00-7.00$ \\
\hline External knowledge & 5.3242 & 0.6194 & $1-7$ & $4.00-6.33$ \\
\hline Environment & 4.8514 & 0.8921 & $1-7$ & $3.00-6.60$ \\
\hline Innovation strategy & 5.8601 & 0.9400 & $1-7$ & $3.75-7.00$ \\
\hline Absorptive & 4.8417 & 0.9805 & $1-7$ & $2.75-7.00$ \\
\hline \multicolumn{5}{|l|}{ Capability } \\
\hline $\begin{array}{l}\text { Financial } \\
\text { perspective }\end{array}$ & 5.1615 & 1.3195 & $1-7$ & $1.00-7.00$ \\
\hline $\begin{array}{l}\text { Customer } \\
\text { perspective }\end{array}$ & 5.2110 & 1.1310 & $1-7$ & $2.00-7.00$ \\
\hline $\begin{array}{l}\text { Internal process } \\
\text { perspective }\end{array}$ & 5.1590 & 1.2510 & $1-7$ & $2.00-7.00$ \\
\hline $\begin{array}{l}\text { Human capital } \\
\text { perspective }\end{array}$ & 4.1674 & 0.9441 & $1-7$ & $2.00-6.00$ \\
\hline
\end{tabular}

\subsection{The Analysis of the Relationship between the Source of Knowledge, Organizational Characteristics and PMS}

For testing the rationality of multicollinearity among the independent variables, we calculate variance inflation factors (VIF) in each of the regression equations (Table 4 to Table 5). Since all of the variance inflation factors within the linear model are below 10, we conclude that multicollinearity is not a significant problem in our analyses (Neter, Wasserman, and Kutner, 1990). From Table 4 we can find that the environmental uncertainty has significant positive impacts on the external knowledge, but there is no significant effect on internal knowledge. Therefore, H1a is supported (EU: t-value $=3.460 * * *$ ). Besides, the innovation strategy also has positive impacts on the internal knowledge and $\mathrm{H} 1 \mathrm{~b}$ is therefore supported (IS: t-value $=3.764 * * *)$. The organization's absorptive capability also has positive impacts on the internal knowledge and H1d is supported (AC: t-value $=7.717 * * *$ ). The result of H1d is also the same with the concepts proposed by Cohen and Levinthal (1990). Besides, when the level of Absorptive capability is high, it will affect the organization to acquire external knowledge (IN: t-value $=7.254^{* * *}$ ). However, H1c is not supported in Table 4 and we can find that the organizational size doesn't have influence on the internal knowledge.

Table 4. The results of hypothesis $\mathrm{H}_{1}(\mathrm{n}=109)$

\begin{tabular}{ccccc}
\hline & \multicolumn{2}{c}{ Internal knowledge } & \multicolumn{2}{c}{ External knowledge } \\
\hline Variables & Coefficient value & t-value & Coefficient value & t-value \\
\hline EU & -0.135 & -1.280 & $\mathbf{0 . 2 6 4}$ & $\mathbf{3 . 4 6 0} * * *$ \\
IS & $\mathbf{0 . 3 1 5}$ & $\mathbf{3 . 7 6 4} * * *^{*}$ & -0.162 & -1.581 \\
Size & -0.129 & -1.191 & -0.089 & -1.115 \\
AC & $\mathbf{0 . 4 9 4}$ & $\mathbf{7 . 7 1 7 * * *}$ & $\mathbf{0 . 5 6 9}$ & $\mathbf{7 . 2 5 4 * * *}$ \\
\hline F-value & $\mathbf{3 3 . 0 8 8 * * *}$ & & $\mathbf{1 6 . 2 8 8 * * *}$ & \\
Adj.R & 0.641 & & 0.459 & \\
Max VIF & 2.107 & & 2.107 & \\
\hline
\end{tabular}

$\mathrm{EU}=$ environment uncertainty ; IS = Innovation strategy ; $\mathrm{AC}=$ Absorptive capability.

$*: \mathrm{P}<01 \quad * *: \mathrm{P}<0.05 \quad * * *: \mathrm{P}<0.01$. 
From Table 5, the results of the regression show that organizations having high level of innovation strategy would also put emphasis on the financial, customer, and internal business process perspectives of PMS. But innovation strategy doesn't have significant impact on human capital perspectives of PMS. Therefore, H2b is supported partially. Besides, the organizational size has significant positive impacts on the four perspectives of PMS. Hence, H2c is supported. The Absorptive capability has the positive impact on the human capital perspective of PMS (AC: $t$-value= $\left.3.926^{* * *}\right)$, but it doesn't have significant impacts on the other dimensions of PMS. Hence, H2d is supported partially. The environmental factors (EU) do not have significant impacts on the four perspectives of PMS. Hence, H2a is not supported. When the organizations apply internal knowledge in innovation activities, it also has a positive impact on the four perspectives of PMS. On the other hand, when the organization applies external knowledge in innovative activities, it puts emphasis only on three PMS (financial, customer, internal business process perspective). Hence, $\mathrm{H}_{3}$ is supported partially.

Table 5. The results of hypothesis $\mathrm{H} 2$ and $\mathrm{H} 3(\mathrm{n}=109)$

\begin{tabular}{|c|c|c|c|c|c|c|c|c|}
\hline \multirow[b]{2}{*}{ Variables } & \multicolumn{2}{|c|}{ Financial perspective } & \multirow{2}{*}{$\begin{array}{c}\text { Customer } \\
\begin{array}{c}\text { Coefficient } \\
\text { value }\end{array}\end{array}$} & \multirow{2}{*}{$\begin{array}{l}\text { perspective } \\
\text { t-value }\end{array}$} & \multicolumn{2}{|c|}{$\begin{array}{l}\text { Internal business } \\
\text { process perspective }\end{array}$} & \multicolumn{2}{|c|}{$\begin{array}{l}\text { Human capital } \\
\text { perspective }\end{array}$} \\
\hline & $\begin{array}{c}\text { Coefficient } \\
\text { value }\end{array}$ & t-value & & & $\begin{array}{l}\text { Coefficient } \\
\text { value }\end{array}$ & t-value & $\begin{array}{l}\text { Coefficient } \\
\text { value }\end{array}$ & t t-value \\
\hline $\mathrm{IK}$ & 0.421 & $3.154 * * *$ & 0.613 & 4.934 & 0.254 & $2.001 * *$ & 0.527 & $4.313^{* * *}$ \\
\hline EK & 0.508 & $4.675 * * *$ & 0.193 & $1.908^{*}$ & 0.215 & $2.077 * *$ & 0.046 & 0.460 \\
\hline EU & -0.004 & -0.039 & -0.022 & -0.259 & -0.146 & -1.583 & 0.079 & 0.942 \\
\hline IS & 0.218 & $1.901 *$ & 0.247 & $2.317 * *$ & 0.372 & 3.418*** & -0.178 & -1.596 \\
\hline Size & 0.154 & $1.893 *$ & 0.414 & $5.465 *$ & 0.298 & $3.848 * * *$ & 0.289 & $3.879 * * *$ \\
\hline $\mathrm{AC}$ & 0.007 & 0.068 & 0.021 & 0.211 & 0.065 & 0.648 & 0.377 & $3.926 * * *$ \\
\hline F-value & \multicolumn{2}{|c|}{$12.736 * * *$} & \multicolumn{2}{|c|}{$16.638 * * *$} & \multicolumn{2}{|c|}{$15.436 * * *$} & \multicolumn{2}{|c|}{$17.589 * * *$} \\
\hline $\operatorname{Adj} \cdot R^{2}$ & \multicolumn{2}{|c|}{0.465} & \multicolumn{2}{|c|}{0.537} & \multicolumn{2}{|c|}{0.517} & \multicolumn{2}{|c|}{0.551} \\
\hline Max VIF & \multicolumn{2}{|c|}{3.593} & \multicolumn{2}{|c|}{3.593} & \multicolumn{2}{|c|}{3.593} & \multicolumn{2}{|c|}{3.593} \\
\hline
\end{tabular}

$\mathrm{EU}=$ environment uncertainty ; IS = Innovation strategy ; $\mathrm{AC}=$ Absorptive capability.

$*: \mathrm{P}<01 \quad * *: \mathrm{P}<0.05 \quad * * *: \mathrm{P}<0.01$.

Table 6. The analysis of PMS between four types of KIB (MANOVA)

\begin{tabular}{|c|c|c|c|c|c|c|c|}
\hline PMS & $\begin{array}{c}\text { A: } \\
\text { Integrator } \\
(n=46)\end{array}$ & $\begin{array}{c}\text { B: } \\
\text { Introduce } \\
(n=38)\end{array}$ & $\begin{array}{c}\text { C: } \\
\text { Creator } \\
(\mathrm{n}=25) \\
\end{array}$ & $\begin{array}{c}\text { D: } \\
\text { Non-KIB } \\
(n=18)\end{array}$ & $\begin{array}{l}\text { Scheffe } \\
\text { analysis }\end{array}$ & F-value & P-value \\
\hline \multirow[t]{2}{*}{ Financial } & & & & & $\mathrm{AB}, \mathrm{AC}$ & & \\
\hline & 5.1174 & 4.3526 & 6.4720 & 4.1556 & $\mathrm{AD}, \mathrm{BC}, \mathrm{CD}$ & 20.644 & 0.000 \\
\hline \multirow[t]{2}{*}{ Customer } & 5.5087 & 4.3105 & 6.0320 & 3.3667 & $\mathrm{AB}, \mathrm{AD}$ & 33.779 & \\
\hline & & & & & $\mathrm{BC}, \mathrm{BD}, \mathrm{CD}$ & & 0.000 \\
\hline \multirow{3}{*}{$\begin{array}{l}\text { Internal } \\
\text { process } \\
\text { Human capital }\end{array}$} & 5.3478 & 4.1667 & 6.3200 & 3.4074 & $\begin{array}{c}\mathrm{AB}, \mathrm{AC}, \\
\mathrm{AD}, \mathrm{BC}, \mathrm{CD}\end{array}$ & 34.926 & 0.000 \\
\hline & & & & & $\mathrm{AB}, \mathrm{AC}$ & & \\
\hline & 4.7609 & 4.1382 & 3.1200 & 3.0556 & $\mathrm{AD}, \mathrm{BC}, \mathrm{BD}$ & 29.351 & 0.000 \\
\hline & & Wilks' Lam & 0.111 & & & 34.213 & 0.000 \\
\hline
\end{tabular}

\subsection{The Analysis of PMS between Four Types of KIB}

The MANOVA analysis of Table 6 shows that different types of PMS significantly vary with different KIBs (Wilks' Lambda $=0.111 ; \mathrm{F}$-value $=34.213 * * *$. The knowledge integrator puts more emphasis on the four perspectives than other KIBs. Therefore, the H4 is supported. 


\section{Conclusion}

The objective of this study is to investigate the differences between the four types of KIB in their organizational characteristics and PMS. Overall, the results provide some empirical evidence on the design of PMS in KIBs. First, scholars classify knowledge as internal or external perspectives (Jordan and Jones, 1997; Zack, 1999), and this study continues the concept and categorizes the KIB into four types: knowledge creator, knowledge introducer, knowledge integrator, and non-KIB. Second, the findings of this study also indicate that different organizational characteristics would affect the acquirement and adoption of internal knowledge and external knowledge, and thus differentiate the four types of KIBs. Table 4 summarizes the difference in the organizational characteristics and two types of knowledge. Third, we investigate the difference between KIB's organizational characteristics and PMS. Based on the regression analysis, there are significant differences in the organizational characteristics and the four perspectives of PMS (Table 5). Finally, this study also finds that there are significant differences in the PMS of the four types of KIBs. According to the results of MANOVA analysis, this study finds that different kinds of KIB give different weights on multiple dimensions of PMS (Table 6).

In the era of knowledge economy, the internal and external knowledge would be the crucial factors to sustain the profitable businesses and consolidate the leading position (Bettencourt et al., 2002). To build an effective PMS is the strategic mechanism for this purpose. This study categorizes the KIBs into four types, including knowledge creator, knowledge introducer, knowledge integrator and non-KIB. This classification is one of the main innovative contributions in the research of KIBs. Besides, many scholars emphasize the importance of multiple dimension of PMS in management accounting (Ittner and Larcker, 2003; Abernethy et al., 2013; Ho, Wu, and Wu, 2014). Kaplan and Norton (1996) propose the concept of BSC, and BSC is also to apply multiple-dimension of PMS. This study extends the research of Kaplan and Norton (1996), Moore et al. (2001) and Cheng and Humphreys (2012), and it divides the PMS of KIBs into financial, customer, internal business process and human capital perspective. And we analyze the difference of PMS among four types of KIB. It is one of the main contributions in the research issue of PMS.

With regards to the organizational characteristics, we find that the companies of KIBs which face higher environmental uncertainty will put more emphasis on the external knowledge. The above results consist with the research of Zack (1999). On the other hand, when the firms put more emphasis on innovation strategy, they would need more internal knowledge for R\&D. It is an extract resemblance with the findings of Cohen and Levinthal (1990). The higher absorptive capability the firm owns, the more important of internal knowledge it puts. However, with regards to the organization size, the firms would not completely put emphasis on the internal knowledge if they are large enterprises. When they are small and middle enterprises, they have their own core competence for competition (Chen and Chen, 2016). Once the enterprises grow or earn profits, and then they often have enough capital for introducing external knowledge by strategic licensing (Giotopoulos, 2014). Hence, they would try to reduce $R \& D$ in-house and advance to knowledge integration. Different types of KIBs build various multiple dimensions of PMS (Table 6). Because the knowledge integrators put more emphasis on the integration of internal and external knowledge, these firms emphasize on all four dimensions. Knowledge introducers pay much attention to strategic licensing or technique transfer from outside firms, and these firms would give a higher weight to human capital perspective than other KIBs for training and fostering employees to transfer and apply technology. Knowledge creators focus on the R\&D in-house, these firms also emphasize on the level of R\&D expenditure, innovation of technique or process, and the demand of customers. Hence, knowledge creators emphasize financial, customer, internal business process perspective of PMS. These findings have never been studied so far and are the other contributions of this study.

This study also proposes management implication to the top management. Empirical results show that there are significant differences in the organizational characteristics and PMS of the four KIB types. When the firms put more emphasis on innovation strategy, they would give more weights to the financial, customer, and internal business process perspective of PMS. If the firms have larger organizational size, they would give more weights on all the four dimensions of PMS. On the other hand, if the firms have higher absorptive capability, they would put emphasis on the human capital perspective of PMS. Given this, PMS has the function to encourage the generation of innovation in individuals by providing useful feedback information. Hence, the influence of the manager in the design of the PMS is either a good or bad strategy depending on the situation (Kruis and Widener, 2014). This study suggests that strategic goals and performance measures are clarified through interpersonal interactions. Because many managers respond positively to performance measures, viewing empowerment as a complement to accountability and as an incentive to action, PMS is capable of supporting delegation whilst enabling strategic alignment (Marginson, 2014). Besides, using performance measures for accountability has a positive effect on 
functional influence when the measures are less specific to the particular function and thus better reflect congruity with strategic goals. Hence,managers outside a particular function may be unable to fully exploit the information found in a diverse set of measures unique to that particular function (Artz et al., 2012).

Some limitations of this study have to be recognized. First, the samples of this study include different kinds of industry (e.g. pharmaceutics, high-tech, management consulting, etc) because of the purpose of external validity. However, Lillis (2002) suggests that field study emphasizes the observation of real management mechanism in depth. For the future studies, we suggest the research could examine few KIBs from single industry. Besides, this study only uses environment, innovation strategy, size and absorptive capacity as organizational contextual factors. We suggest that future studies could add organizational structure (O'Connor et al., 2005) or organizational culture (Henri, 2006) to test whether any difference exists in the PMS. Because Arnold and Artz (2015) suggest that a firm's "business model" must be understood before performance measures can be chosen and implemented, we suggest that the future research could use the integrative perspectives of business model to design the PMS.

\section{Acknowledgements}

The authors would like to thank the Ministry of Science and Technology of Taiwan (R.O.C) for financially supporting this research (MOST 104-2410-H-025-009 -)

\section{References}

Abernethy, M. A., Bouwens, J., \& Lent, L. (2013). The role of performance measures in the intertemporal decisions of business unit managers. Contemporary Accounting Research, 30 (3), 925-961. http://dx.doi.org/ 10.1111/j.1911-3846.2012.01178.x

Arnold, M. C. \& Artz, M. (2015). Target difficulty, target flexibility, and firm performance: evidence from business units' targets. Accounting, Organizations and Society, 40(1), 61-77. http://dx.doi.org/ 10.1016/j.aos.2014.12.002

Artz, M., Homburg, C., \& Rajab, T. (2012). Performance-measurement system design and functional strategic decision influence: the role of performance-measure properties. Accounting, Organizations \& Society, 37(7), 445-460. http://dx.doi.org/ 10.1016/j.aos.2012.07.001

Bai, G., Coronado, F., \& Krishnan, R. (2010). The role of performance measure noise in mediating the relation between task complexity and outsourcing. Journal of Management Accounting Research, 22(1), 75-102. http://dx.doi.org/ 10.2308/jmar.2010.22.1.75

Bettencourt, L. A., Ostrom, A. L., Brown, S. W., \& Roundtree, R. I. (2002). Client co-production in knowledge-intensive business service. California Management Review, 44(4), 100-128. http://dx.doi.org/ $10.2307 / 41166145$

Biege, S., Lay, G., Zanker, C., \& Schmall, T. (2013). Challenges of measuring service productivity in innovative, knowledge-intensive business services. The Service Industries Journal, 33(3-4), 378-391. http://dx.doi.org/ $10.1080 / 02642069.2013 .747514$

Chen, S. L. \& Chen, L. Y. 2016. The Effects of Customers' Bargaining Power on Capital Expenditure and Earnings Management: Evidence from Taiwan. Accounting and Finance Research, 5 (3), 12-28. http://dx.doi.org/ 10.5430/afr.v5n3p12

Chenhall, R. H. \& Morris, D. (1986). The impact of structure, environment, and interdependence on the perceived usefulness of management accounting system. The Accounting Review, 61(1), 16-35. www.jstor.org/stable/247520

Cheng, M. M. \& Humphreys, K. A. (2012). The differential improvement effects of the strategy map and scorecard perspectives on managers' strategic judgments. The Accounting Review, 87(3), 899-924. http://dx.doi.org/ 10.2308/accr-10212

Child, J. (1972). Organizational structure, environment and performance: the role of strategic choice. Sociology, 6 (1), 1-22. http://dx.doi.org/ 10.1177/003803857200600101

Çiçek, M. C., Köksal, G., \& Özdemirel, N. E (2005). A team performance measurement model for continuous improvement. Total Quality Management \& Business Excellence, 16(3), 331-349. http://dx.doi.org/ 10.1080/14783360500054129

Cohen, W. M. \& Levinthal, D. A. (1990). Absorptive capacity: a new perspective on learning and innovation. Administrative Science Quarterly, 35(1), 128-152. http://dx.doi.org/ 10.2307/2393553 
Conant, J. S., Mokwa M. P. \& Varadarajan, P. R. (1990). Strategic types, distinctive marketing competencies and organization performance: a multiple measures-based study. Strategic Management Journal, 11(5), $365-383$. http://dx.doi.org/ 10.1002/smj.4250110504

Cuieford, J. P. (1965). Fundamental statistics in psychology and education. New York, NY: McGraw-Hill.

Demeré, B. W., Krishnan, R., Sedatole, K. L., \& Woods, A. (2016). Do the incentive effects of relative performance measurement vary with the ex ante probability of promotion? Management Accounting Research, 30, 18-31. http://dx.doi.org/10.1016/j.mar.2015.09.002

Ditillo, A. (2004). Dealing with the uncertainty in knowledge-intensive firms: the role of management control systems as knowledge integration mechanisms. Accounting, Organizations and Society, 29(3-4), 401-421. http://dx.doi.org/ 10.1016/j.aos.2003.12.001

Duncan, R. B. (1972). Characteristics of organization environment and perceived environmental uncertainty. Administrative Science Quarterly, 17(3), 313-327. http://dx.doi.org/ 10.2307/2392145

Giotopoulos, I. (2014). Dynamics of firm profitability and growth: do knowledge-intensive (business) services persistently outperform? International Journal of the Economics of Business, 21(3), 294-319. http://dx.doi.org/10.1080/13571516.2014.921364

Gopalakrishnan, M., Libby, T., Samuels, J. A., \& Swenson, D. (2015).The effect of cost goal specificity and new product development process on cost reduction performance. Accounting, Organizations and Society, 42(1), 1-11. http://dx.doi.org/ 10.1016/j.aos.2015.01.003

Gordon, L. A. \& Narayanan, V. K. (1984). Management accounting systems, perceived environmental uncertainty and organization structure: an empirical investigation. Accounting, Organizations and Society, 9(1), 33-47. http://dx.doi.org/ 10.1016/0361-3682(84)90028-X

Henri, J. F. (2006). Organizational culture and performance measurement systems. Accounting, Organizations and Society, 31(1), 77-103. http://dx.doi.org/ 10.1016/j.aos.2004.10.003

Ho, J. L. Y., Wu, A., \& Wu, S. Y. C. (2014). Performance measures, consensus on strategy implementation, and performance: evidence from the operational-level of organizations. Accounting, Organizations and Society, 39(1): 38-58. http://dx.doi.org/ 10.1016/j.aos.2013.11.003

Hurley, R. F. \& Hult, T. M. (1998). Innovation, market orientation, and organization learning: an integration and empirical examination. Journal of Marketing, 62(3), 42-54. http://dx.doi.org/ 10.2307/1251742

Ittner, C. D. \& Larcker, D. F. (1997). Quality strategy, strategic control systems, and organization performance. Accounting, Organizations and Society, 22(3-4), 293-314. http://dx.doi.org/ 10.1016/S0361-3682(96)00035-9

Ittner, C. D. \& Larcker, D. F. (1998). Innovations in performance measurement: trends and research implications. Journal of Management Accounting Research, 10, 205-238. http://ssrn.com/abstract=137278

Ittner, C. D. \& Larcker, D. F. (2001). Accessing empirical research in management accounting: a valued-based management perspective. Journal of Accounting and Economics, 32(1-3), 349-410. http://dx.doi.org/10.1016/S0165-4101(01)00026-X

Ittner, C. D. \& Larcker, D. F. (2003). Performance implications of strategic performance measurement in financial services firms. Accounting, Organizations and Society, 28(7-8), 715-741. http://dx.doi.org/ $10.1016 / \mathrm{S} 0361-3682(03) 00033-3$

Jordan, J. \& Jones, P. (1997). Assessing your company's knowledge management style. Long Range Planning, 30(3), 392-398. http://dx.doi.org/ 10.1016/S0024-6301(97)90254-5

Kaplan, R. S. \& Norton, D. P. (1996). The balanced scorecard: translating strategy into action. Boston, MA: Harvard Business School Press.

Kerlinger, F. N. (1986). Foundation of Behavior Research. Fort Worth, TX: Holt, Rinehart and Winston.

Kruis, A. M. \& Widener, S. K. (2014). Managerial influence in performance measurement system design: a recipe for failure? Behavioral Research in Accounting, 26 (2), 1-34. http://dx.doi.org/ 10.2308/bria-50755.

Leonard-Barton, D. (1995). Wellsprings of knowledge: building and sustaining the sources of innovation. Boston, MA: Harvard Business School Press.

Lillis, A. M. (2002). Managing multiple dimensions of manufacturing performance: an exploratory study. Accounting, 
Organization and Society, 27(6), 497-529. http://dx.doi.org/ 10.1016/S0361-3682(01)00032-0

Marginsona, D., McAulayb, L., Roushc, M., \& Zijl, T. V. (2014). Examining a positive psychological role for performance measures. Management Accounting Research, 25 (1), 63- 75. http://dx.doi.org/ 10.1016/j.mar.2013.10.002

Marjanovic, O. \& Freeze, R. (2012). Knowledge-intensive business process: deriving a sustainable competitive advantage through business process management and knowledge management integration. Knowledge \& Process Management, 19(4), 180-188. http://dx.doi.org/ 10.1002/kpm.1397

Miozzo, M., Desyllas, P., Lee, H. F., \& Miles, I. (2016). Innovation collaboration and appropriability by knowledge-intensive business services firms. Research Policy, 45(7), 1337-1351. http://dx.doi.org/10.1016/j.respol.2016.03.018

Moore, C., Rowe, J. B., \& Widener, S. K. (2001). HCS: designing a balanced scorecard in a knowledge-based firm. Issues in Accounting Education, 16(4), 569-601. http://dx.doi.org/10.2308/iace.2001.16.4.569

Murray, J. Y., Kotabe, M., \& Westjohn, S. A. (2009). Global sourcing strategy and performance of knowledge-intensive business services: a two-stage strategic fit model. Journal of International Marketing, 17(4), 90-105. http://dx.doi.org/ 10.1509/jimk.17.4.90

Najafi-Tavani, Z., Zaefarian, G., Henneberg, S. C. Naude, P., Giroud, A., \& Andersson, U. (2015). Subsidiary knowledge development in knowledge-intensive business services: a configuration approach. Journal of International Marketing, 23 (4), 22-43. http://dx.doi.org/10.1509/jim.14.0150

Neter, J., Wasserman, W. \& Kutner, M. H. (1990). Applied linear statistical models. Irwin, OH: Homewood.

O'Connor, N. G., Deng, J., \& Luo, Y. (2005). Political constraints, organization design and performance measurement in China's state-owned enterprises. Accounting, Organizations and Society, 30(5), 157-177. http://dx.doi.org/ 10.1016/j.aos.2005.01.005

Padmore, T., Schuetze. H., \& Gibson, H. (1998). Modeling systems of innovation: an enterprise-centered view. Research Policy, 26(6), 605-624. http://dx.doi.org/ 10.1016/S0048-7333(97)00039-5

Riasi, A., \& Asadzadeh, N. (2016). How coercive and legitimate power relate to different conflict management styles: a case study of Birjand high schools. Journal of Studies in Education, 6(1), 147-159. http://dx.doi.org/ $10.5296 /$ jse.v6i1.8946

Robinson, K. C. \& McDougall, P. P. (1998). The impact of alternative operationalizations of industry structural elements on measures of performance for entrepreneurial manufacturing ventures. Strategic Management Journal, 19(11), 1079-1100. 10.1002/(SICI)1097-0266(1998110)19:11<1079::AID-SMJ997>3.0.CO;2-1

http://dx.doi.org/

Santos, J. B. \& Spring, M. (2015). Are knowledge intensive business services really co-produced? Overcoming lack of customer participation in KIBS. Industrial marketing management,50, 85-96. http://dx.doi.org/ 10.1016/j.indmarman.2015.04.005

Sari, R. N. \& Basri, R. M. (2015). The moderating effect of goal setting on performance easurement mystem-managerial performance relationship. Procedia Economics and Finance, 31, 876-884. http://dx.doi.org/10.1016/S2212-5671(15)01185-5

Thomas, H. (1998). Performance measurement systems, incentives, and the optimal allocation of responsibilities. Journal of Accounting and Economics, 25(3), 321-347. http://dx.doi.org/ 10.1016/S0165-4101(98)00024-X

Veugelers, R. \& Cassiman, B. (1999). Make or buy in innovation strategies: evidence from Belgian management firms. Research Policy, 28(1), 63-80. http://dx.doi.org/ 10.1016/S0048-7333(98)00106-1

Zack, M. H. (1999). Developing a knowledge strategy. California Management Review, 41(3), 125-145. http://dx.doi.org/ 10.2307/41166000 


\section{Appendix: measurement items}

1. The sources of knowledge (Leonard-Barton, 1995; Jordan and Jones, 1997; Zack, 1999)

The primary sources of the core operational and managerial knowledge in your firms are from: (extremely disagreement (1) to extremely agreement (7))

(1) The creation or development of the R \& D department in the firm.

(2) The cooperation among inter-departments in the firm.

(3) The cooperation among inter-departments in the firm.

(4) Strategic licensing or inter-organizational alliances outside the firm.

(5) Research institutes (e.g. universities, government agencies, consultant vendors, etc).

(6) Information acquired outside the firm (e.g. publications, journals, books, professional associations, conferences, etc).

2. Environment (Child,1972; Gordon and Narayanan, 1984)

(1) How would you classify the marketing activities of your competitors during the past 5 years?

Become more predictable $\square \square \square \square \square \square \square$ Become less predictable

(2) During the past 5 years, the tastes and preferences of your customers have become:

Much easier to predict $\square \square \square \square \square \square \square$ Much harder to predict

(3) How many new products and/or services have been marketed during the past 5 years by your industry?

None $\square \square \square \square \square \square \square$ Many

(4) How often do new scientific discoveries emerge in your industry

Seldom $\square \square \square \square \square \square \square$ Frequently

(5) During the past 5 years, the legal, political and economic constraints surrounding your firm have?

Remained about the same $\square \square \square \square \square \square \square$ Have proliferated greatly

3. Innovation (extremely disagreement (1) to extremely agreement (7)) (Conant et al., 1990)

(1) Comparing with other main competitors, the products we provide to our customers are more innovative and continually changing.

(2) Comparing with other main competitors, the image of my company is more innovative and creative.

(3) Comparing with other main competitors, the competencies of our managers are more broad, entrepreneurial, diverse and flexible.

(4) Comparing with other main competitors, our managers care more about the development of new products and new market.

4. Size (Veugelers and Cassiman, 1999)

The number of employees : $\square$ Under $50 \quad \square 51 \sim 100 \quad \square$ 101 200 $\square 201 \sim 500 \quad \square 501 \sim 1000 \quad \square 1001 \sim 2000$ $\square$ Above 2000

5. Absorptive capacity (Very low (1) to very high (7)) (Cohen and Levinthal,1990)

(1) To what extent of your company to apply different sources of knowledge in designing and manufacturing the products.

(2) To what extent of your company to apply different sources of knowledge in developing the marketing strategy.

(3) To what extent of your company to apply different sources of knowledge in the managerial activities.

(4) To what extent of your company to apply different sources of knowledge in the operational activities.

6. Performance measurement system (not used at all (1) to used to a great extent (7))

(1) Financial perspective (Kruis and Widener, 2014):

$$
\mathrm{ROE}=(\text { Net income }) /(\text { Average common stockholders' equity) }
$$


$\mathrm{ROA}=($ Operating income after-tax $) /($ Average total assets)

Sales growth rate $=($ Sales from current term - Sales from last term $) /($ Sales from last term $)$

(2) Customer perspective (Kaplan and Norton, 1996):

Market share: Reflects the proportion of business in a given market that a business unit sells.

Customer retention: Tracks, in absolute or relative terms, the rate at which a business unit retains or maintains ongoing relationships with its customers.

Customer acquisition: Measures, in absolute or relative terms, the rate at which a business unit attracts or wins new customers or business.

Customer satisfaction: Assesses the satisfaction level of customers along specific performance criteria within the value proposition.

Customer profitability: Measures the net profit of a customer, or a segment, after allowing for the unique expenses required to support that customer.

(3) Internal business process perspective (Kaplan and Norton, 1996; Cheng and Humphreys, 2012):

The saving in process time and cost $=$ (Processing time) / (Throughput time) or (Processing cost) / (Throughput cost)

Customer-response time $=$ The duration from the time a customer places an order for a product or service to the time the product or service is delivered to the customer.

$\square$ The ratio of customer complain= Percentage of customers reporting complaints about products or services

(4) Human capital perspective (Moore et al., 2001):

Employee satisfaction: Involvement with decision, recognition for doing a good job, access to sufficient information to do the job well, overall satisfaction with company.

$\square$ Voluntary separation rate $=$ (Voluntary separation) $/$ (Headcount)

$\square$ Training cost percentage $=($ Total training cost $) /($ Operating expense $)$ 